\title{
Three Spheres of Classification Research: Emergence, Encyclopedism, and Ecology
}

\author{
Joseph T. Tennis \\ Information School \\ University of Washington, Seattle \\ jtennis@u.washington.edu
}

\section{INTRODUCTION}

Three paths of interdisciplinary work shape the future of classification research. They are emergence, encyclopedism, and ecology. Each of these, in method, approach, and in substantive inquiry outline both the boundaries and the intersections of the many fields that contribute to our overall understanding of classification research. This paper outlines some high level claims of this work, ties it to current research and offers some theoretical applications of these paths.

\section{EMERGENCE}

Emergence is "the rise of a system that cannot be predicted or explained from antecedent conditions," (Encyclopædia Britannica, 1974). Emergence is distinguished from resultants. The latter phenomena "are predictable from their constituent parts" (Encyclopædia Britannica, 1974a) and the former are not. An example would be a physical mixture of talcum powder and sand versus a chemical compound such as salt which does not resemble its constituent parts: sodium and chlorine. This simple metaphor of emergence is at work in many evolutionary theories in biology. Some are contentious. Others are finding new validity in light of recent theories. Beyond biology and into the realm of knowledge, Michael Polanyi has found emergence to be a powerful explanation for why we know what we know, how we build new ideas when our knowledge becomes tacit, (Polanyi, 1966). Still others in the philosophy of the mind relate this idea to the inability for cognitive science to explain thought through mechanistic calculations of brain architectures and processes.

Still further relevant to the latter two paths of encyclopedism and ecology below, is the role of context in theories of emergence. Self-organizing systems, the trans-disciplinary study of emergence, rely on objects (in a system) and their relationship with their environment or their context (Johnson, 2001). Each of these objects, when placed in the system creates something greater than the whole; that is to say, something else emerges. Thus, for Johnson, a group of ants, given the parameters of their context (in a laboratory environment) self organize. They create something greater than the sum of their population. A colony emerges. He finds this true for other objects in other contexts. Like Polanyi with knowledge, the parts that we have, give rise to something greater than the sum of those parts. We have new emergent knowledge.

Each of these examples gives rise to, through emergence, a schematic of levels. That is, we must have parts to have sums of those parts, and if there are emergent properties (like colonies or new knowledge) we have yet another level. Emergence builds and builds. Emergent theories in 
biology have acknowledged this. So too has classification research. The emergent theories in biology have five stages of the evolutionary process:

The evolutionary account of life is a continuous history marked by stages at which fundamentally new forms have appeared: (1) the origin of life; (2) the origin of nucleus-bearing protozoa; (3) the origin of sexually reproducing forms, with an individual destiny lacking in cells that reproduce by fission; (4) the rise of sentient animals, with nervous systems and protobrains; and (5) the appearance of cogitative animals, namely humans. Each of these new modes of life, though grounded in the physicochemical and biochemical conditions of the previous and simpler stage, is intelligible only in terms of its own ordering principle. These are thus cases of emergence, (Encyclopædia Britannica, 1974a).

In classification research there are many examples of these levels of complexity. Perhaps the most prominent is the theory of integrative levels. And they organized the levels for classification as this (Spiteri, 1995):

\author{
Physical Entities \\ Chemical Entities \\ Heterogeneous, Non-Living Entities \\ Artefacts \\ Biological Entities \\ Man \\ Mentefacts (Huckaby 1972; Wilson 1972)
}

Currently, the classification scheme used by Knowledge Organization to organize its bibliography of classification research is the International Coding Classification (ICC), which is based on the theory of integrative levels (Dahlberg, 1982). Yet, there is more to emergence than levels.

In classification, when symbols of concepts are placed into interrelationship with one another, gaps emerge. This has been discussed in the literature as well. Barbara Kwasnik (1992) discusses the role of classification schemes in shaping theory. She uses the periodic table as one such structure that was able to cast light on questions in the weight of elements. Foskett (1991) poses a similar set of questions to specialized classification schemes. In a faceted classification scheme he argues, combining facets not yet combined in your collection would point to gaps in the research field, and therefore constitute topics for further research.

And it is in that role, the signpost to research that emergence poses a more practical role in classification research. What stock has classification research in the particles of research it has contributed? And more to the point, where is the emergent knowledge, greater than the sum of individual papers? What new knowledge emerges from classification research contributions to the existing corpus on information organization?

A fascinating theoretical example of emergence in classification research comes from $\mathrm{S}$. R. Ranganathan's idea of Abstract Classification (1967). In the concluding chapter of his 1967 
Prolegomena Ranganathan asks the reader to consider a field of study that emerges from his work in facet and analytico-synthetic classification theory. This field of study would synthesize and draw conclusions based on the sum of work done in the other two parts of his classification theory work. This work has been little used.

\section{ENCYCLOPEDISM}

Many researchers have looked to synthesize extant work in classification research. Birger Hjorland is one such thinker. His Domain Analysis (Hjorland, 2002) pulls together various methods or approaches to studying a domain. By doing so, an information scientist, specifically one interested in knowledge organization, would create documentation related to the various forces at work in a given domain. The resulting text might be considered an encyclopedic description of that domain. By acknowledging the complexities in approach and in recording and making accessible those complex forces, an information scientist as an expert in this domain would be creating intellectual access to the various forces at work in this domain. This makes explicit the motives of a specific knowledge organization scheme.

On a practical level, this is akin to what Umberto Eco (1984) has considered at work in dictionaries and other classificatory structures (writ large). Eco points to the invisible encyclopedia behind every dictionary we use. He says, in his chapter on the "Dictionary vs. Encyclopedia" in the subsection "Critique of the Porphyrian Tree" where the tree is a dictionary, that:

The tree of genera and species, the tree of substances, blows up in a dust of differentiae, in a turmoil of infinite accidents, in a nonhierarchical network of qualia. The dictionary is dissolved into a potentially unordered and unrestricted galaxy of pieces of world knowledge. The dictionary thus becomes an encyclopedia, because it was in fact $a$ disguised encyclopedia, $\left(\mathrm{Eco}, 1984\right.$, p. 68) ${ }^{1}$

This disguised encyclopedia is perhaps at work when we look at the purposes and biases of classification schemes. Were classification research to embrace this tension, and move forward with research and documentation like what might be generated with something like domain analysis, we can foster understanding in the structures that are at work in information access (i.e. classification schemes).

In another real way, encyclopedism is about narrative. Narratives in encyclopedic structures tell us any number of why's, what's, how's, where's, and so on. They bring us gently into the subject matter and lead us gently into further reading. Narrative has been used in knowledge organization structures from at least the fifth century onward, (Collison, 1964). Further, narrative has been a discussion point in knowledge access by Beghtol (1998) among others. Narrative, coupled with the ideas of embodied classification (Jacob, 2002), that will be discussed in the section that follows, finds purchase in the work of what is called third generation knowledge management (Snowden, 2002). This focus on narrative seeks to construct narrative databases, train story tellers, and foster a relationship in the organization called cynefin (pronounced kun-ev'in). Cynefin is: 


\begin{abstract}
A Welsh word with no direct equivalent in English. As a noun it is translated as 'habitat,' as an adjective to convey 'acquainted' or 'familiar.' A more poetic, definition comes from the The Land and the Sea, a collection of paintings by Kyffin Williams, a distinctively Welsh artist whose use of oils creates a new awareness of the mountains of his native land and their relationship to the spirituality of its people: 'It describes that relationship: the place of your birth and of your upbringing, the environment in which you live and to which you are naturally acclimatised' (N. Sinclair 1998). (Cynefin Centre, 2002)
\end{abstract}

This concept of Cynefin ${ }^{2}$ then, especially with its accompanying documentation, is a metaphor for an embodied encyclopedia that is used by Snowden and his center to talk about and consult on knowledge management. This kind of work links knowledge organization research to the field of practice in a robust way. It forges links that move beyond rational structures of taxonomies (that are necessary for much knowledge management work); into a more whole organization knowledge organization that points to fruitful research prospects. This whole organization perspective, when viewed broadly, can be seen as an ecological perspective.

\title{
4. ECOLOGY
}

An ecology is a system of interdependencies. The study of ecology is the "study of the relationships between organisms and their environment," (Encyclopædia Britannica, 1974a). The ecology metaphor has been fruitful for classification research. By examining the individual in his or her environment, classification theory has looked at theoretical models of embodied mind (Lakoff \& Johnson, 1980; Jacob, 2002). This is further studied by Bowker and Star in the everyday life of classification (1999). Star and Ruhleder (1996) put forth a related idea of technological infrastructure. This is tied to classification by Jacob and Albrechtsen (1998). The driving factor in all of this work is the ecological study of classification in its context - in its functioning in the organization or the domain in which it resides. However, this study of context along side the individuals is only as good as the study of the classificatory structures that might be used as tools in these environments. The study of classification though, necessarily interested in the contexts in which classification takes place, must also study those mechanisms that are the tools of classification praxis as well.

The ecology, its tools, its environment, and the individuals in it, are the context of classification. So too in their own ways are the levels that surface from emergent theory, so too is the narrative told by encyclopedic structures. These paths of the possible future of classification research contextualize classification - and necessarily in a formal way. Each of these paths, metaphorically, and beyond, can shape perceptions of the contexts in which classification resides, and therefore shapes classification.

\section{APPLICATION}

I see the application of these three spheres of emergence, encyclopedism, and ecology as themes for collaboration among classification researchers. These spheres and others as umbrella 
concepts could help identify partners in collaborative projects or teams of experts who might work, for example, on recommendations and white papers. Each of these spheres may generate their respective digital workspace that would allow for computer supported collaborative work by many. To this end, scholars might apply these three spheres to future classification research as unifying metaphors.

There is also the self-reflective application of these three spheres to classification research itself. What is the ecology of classification research? What are the channels of communication in this field? What are the genres of publication and information sharing? What is the narrative (encyclopedism) that classification research tells itself? What is emergent from classification research systems? For example, how do researchers make use of the revisions and the data about revisions of the Dewey Decimal Classification (DDC)? This material is kept by the editors of the DDC and might be useful for systems design (Tennis, 2002). Further, much work is done into the cause and results of bias in classification schemes. What are the results from these analyses? What emerges from this work? As researchers in this field comment on the future of classification research, it might be fruitful to consider the various endeavors of classification research moving toward a whole-picture view of research into, and design of, classification systems - toward an ecological approach to classification research - employing various methodologies and exploring various interrelationships between these and other spheres.

\section{CONCLUSION}

Emergence, encyclopedism, and ecology are metaphors for the paths classification research should continue to pursue. If that is to be the case, a systematic understanding and synthesis of the literature in these areas might find publication in web form. Due to space constraints I was not able to provide anything but a broad level overview. However, some questions remain that shape the logistics of our journey down any of these three paths. What does classification research know in these areas? What has yet to be done? This is up to classification research as a group to decide. At the end of the Elsinore Conference in 1964, the conference participants enumerated the various points for future research, and points of concern for the field of classification research. Of note, in the section on New Directions in Theoretical Research, they noted, "the study of various methods for embodying "analytic", relations given by context" was needed. It still is. This position paper proposes three metaphorical paths along which those investigations into context can be systematized. Further those three paths, emergence, encyclopedism, and ecology, are not new or foreign fields. Rather, these three paths are of central concern to the research in classification theory.

\section{NOTES}

1 This is not an unproblematic quote from Eco. His thought has changed over time, and his discussion of the relationship between the dictionary and the encyclopedia is of central concern to him. I am using this quote to serve my purpose, with only this footnote to serve as the nod to the complex discourse surrounding his changing opinion about these central metaphors in his work.

2 Cynefin can in itself be considered an example of emergent layer of conceptualization. We can understand, because of its name, the difference between it and its constituent parts. Further, 
because it is a term related to but different that Ba (Nonaka and Konno, 1998), it allows new investigation into its context and its relationships to knowledge organization work.

\section{REFERENCES}

Beghtol, C. (1998). Knowledge Domains: Multidisciplinarity and Bibliographic Classification Systems. Knowledge Organization, 25(1/2): 1-12.

Bowker, G. \& Star, S. L. (1999). Sorting Things Out: Classification and its Consequences. Cambridge MA: MIT Press.

Collison, R. (1964). Encyclopaedias: Their History throughout the Ages, New York: Hafner.

Cynefin Centre. (2002). Cynefin Centre for Organisational Complexity website. Retrieved from http://www-1.ibm.com/services/cynefin/.

Dahlberg, I. (1982). ICC - Information Coding Classification - Principles, Structure and Application Possibilities. International Classification, 9(2): 87-93.

Eco, U. (1984). Semiotics and the Philosophy of Language. London: Macmillan Press.

Encyclopædia Britannica (1974a). Ecology. Retrieved 7/2002 from http://www.search.eb.com/eb/article?eu=119739.

Encyclopædia Britannica (1974b). Emergence. Retrieved 7/2002 from http://www.search.eb.com/eb/article?eu=33091.

Foskett, D. (1991). Concerning general and special classifications. International Classification. 18(2): 87-91.

Hjorland, B. (2002). Domain Analysis: Eleven Approaches Innovative and Traditional. Journal of Documentation, 58(4): 422-462.

Huckaby, S. (1972). An enquiry into the theory of integrative levels as the basis for a generalized classification scheme. Journal of Documentation, 28(2): 97-106.

Jacob, E. (2002). Augmenting Human Capabilities: Classification as Cognitive Scaffolding. Advances in Classification Research: Challenges in Knowledge Organization for the $21^{\text {st }}$ Century. Integration of Knowledge across Boundaries. Proceedings of the Seventh International ISKO Conference 10-13 July 2002 Granada, Spain. Vol. 8: 38-44.

Jacob, E. \& Abrechtsen, H. (1998). When Essence Becomes Function: Post-Structuralist Implications for an Ecological Theory of Organizational Classification Systems. In Wilson, T. D. \& Allen, D. K. (Eds.), Exploring the contexts of information behaviour: proceedings of the Second International Conference on Research in Information Needs. Seeking and Use in Different Contexts 13/15 August, 1998, Sheffield. UK. London: Taylor Graham.

Johnson, S. (2001). Emergence : the connected lives of ants, brains, cities, and software. New York: Scribner.

Kwasnik, B. (1992). The Role of Classification Structures in Reflecting and Building Theory. Advances in Classification Research, 3: 63-81.

Lakoff, G. \& Johnson, M. (1980). Metaphors we live by. Chicago: University of Chicago Press.

Nonaka, I. \& Konno, N. (1998). The Concept of "Ba": Building a Foundation for Knowledge Creation. California Management Review, 40(3).

Polanyi, M. (1966). Tacit Dimension. Garden City, NY: Doubleday.

Sinclair, N. (1998). Preface. In Williams, K. (Ed.) The Land and the Sea. Llandysul, Wales: Gomer. 
Snowden, D. (2002). Complex Acts of Knowing: Paradox and Descriptive Self-awareness. Journal of Knowledge Management, May 6(2). Retrieved 7/2002 from http://www1.ibm.com/services/files/Complexactsofknowing_1.pdf.

Spiteri, L. (1995). The Classification Research Group and the Theory of Integrative Levels. Katherine Sharp Review, 1. Retrieved 7/2002 from http://alexia.lis.uiuc.edu/review/summer1995/spiteri.html.

Star, S. \& Ruhleder, K. (1996). Steps toward an ecology of infrastructure: design and access for large information spaces. Information Systems Resarch 7: 111-134.

Tennis, J. T. (2002). Subject ontogeny: subject access through time and the dimensionality of classification. Advances in Classification Research: Challenges in Knowledge Organization for the $21^{\text {st }}$ Century. Integration of Knowledge across Boundaries. Proceedings of the Seventh International ISKO Conference 10-13 July 2002 Granada, Spain. vol. 8: 54-59.

Wilson, T. D. (1972). The work of the British Classification Research Group. In Wellisch, H. \& Wilson, T.D. (Eds.), Subject Retrieval in the Seventies (pp.62-71.) Westport, CT: Greenwood. 